\title{
Industrial Home Work and Fordism in Western Europe
}

\author{
Women's Activism, Labour Legislation and Union's Mobilization in Golden \\ Age Italy, 1945-75
}

\section{Eloisa Betti}

Industrial home work was the backbone of Italy's industrial system in the country's most important period of economic growth in the twentieth century, the boom years of $1945^{-75}$ known as the Golden Age. The home-based economy grew together with the expansion of Fordist large-scale factory manufacturing rooted mainly in the northern regions. The dualistic nature of Italy's economic structure $^{1}$ together with the dominance of medium-size industrial companies and workshops ${ }^{2}$ laid the ground not only for the survival of industrial home work, which was thought to be a backward practice, but also for its renewed spread. In the 1970s, the crisis of the Fordist system led to a large expansion of home-based work, ${ }^{3}$ revealing its persistence through and beyond the Golden Age of the twentieth century.

Industrial home work became increasingly feminized during these years. While young adult men entered the factories en masse, only a small proportion of young women did so. In the process of transition from agricultural to industrial dominance in the 1950s, an increasing number of rural women as well as former factory workers became industrial home workers. On the one hand, the employment structure of the boom years clearly revealed a gender pattern, by which women did not benefit in the same way as men from the economic

1 Vera Lutz, "The Growth Process in a Dual Economic System", Banca Nazionale del lavoro Quarterly Review, 9 (1958), pp. 279-324 ; Augusto Graziani, "Dualismo e sottosviluppo nell'economia italiana", Nord e Sud, 2 (1963), pp. 24-32; Lucio Cafagna, Dualismo e sviluppo nella storia d'Italia (Venice, 1989).

2 Micael Piore and Charles Sabel, The second industrial divide: Possibilities for prosperity (New York, 1984); Sebastiano Brusco, "The Emilian model: Productive decentralization and social integration", Cambridge Journal of Economics, 6 (1982), pp. 167-84; Andrea Colli and Michelangelo Vasta (eds), Forms of Enterprise in 2oth Century Italy: Boundaries, Structures and Strategies (Cheltenham, 2010).

3 Luigi Frey (ed.), Lavora domicilio e decentramento dell'attività produttiva nei settori tessile e dell'abbigliamento in Italia (Milan, 1975).

(C) ELOISA BETTI, 2022 | DOI:10.1163/9789004499614_014

This is an open access chapter distributed under the terms of the CC BY-NC-ND 4.o license. 
growth. ${ }^{4}$ On the other hand, adult women with family responsibilities faced workplace discrimination. Only in 1963 did parliament pass a law to stop the dismissal of women from jobs upon marriage. Moreover, due to a lack of publicly provided child care, they had little support in combining work and family duties. ${ }^{5}$

At the same time, a growing chorus demanded regulation of home-based work. Women's associations, women politicians and unionists played a major role in denouncing the conditions of such labour. Industrial home workers themselves mobilized in the 196os-1970s, rallying in public spaces and debating their working and living conditions in informal gatherings as well as official conferences. In the social conflict and labour unrest that spread all over Italy from the late 196os, home workers joined female factory workers in strikes. They too demonstrated to obtain better pay and proper labour contracts. The mobilization of home workers, along with the commitment of unionists and politicians, was crucial for creating the basis for regulation in the wake of 1968. The chronology of legal regulation in Italy, with action in 1958 and 1973, both reveals the pervasiveness of industrial home work in itself and the widespread perception of its significance well before the international discussion in the 198 os that led to ILo Convention No. 177 in $1996 .^{6}$

The global expansion of industrial home work in the last three decades pushes us to come to terms with national and international historiographies, to understand the actual role of home-based work in different phases of industrial and post-industrial capitalism. Earlier studies by Eileen Boris, Elisabeth Prügl and Cynthia Daniels connected industrial capitalism of the nineteenth century and early twentieth century with the post-Fordist 1980 os and 1990s. ${ }^{7}$ During the latter phase, the diffusion of home work in the global South as well as in countries of the North, in particular among groups of Asian and Latin American migrants, generated new research questions concerning the role of industrial home work in the global economy in the long term. ${ }^{8}$ The Italian case

4 Eloisa Betti, "Women's Working Conditions and Job Precariousness in Historical Perspective: The Case of Italian Industry during the Economic Boom (1958-1963)", in Isabella Agárdi, Berteke Waaldijk and Carla Salvaterra (eds), Making Sense, Crafting History: Practices of Producing Historical Meaning (Pisa, 2010), pp. 175-205.

5 Perry Wilson, Women in 2oth century Italy (Basingstoke, 2009).

6 Eileen Boris' chapter in this volume, "From Industrial Evil to Decent Work: The ILO and Changing Perspectives towards Home-Based Labour".

7 Eileen Boris and Cynthia R. Daniels (eds), Homework: Historical and contemporary perspectives on paid labor at home (Urbana, 1989); Eileen Boris and Elisabeth Prügl (eds), Homeworkers in global perspective: Invisible no more (New York, 1996).

8 See Marlese van Broembsen and Jenna Harvey's chapter in this volume, "Realizing Rights for Home Workers: Participating in Global Supply Chains". 
is of particular interest due to the important number of existing sources for the under-researched period of Fordism. Italian historiography almost exclusively has addressed the phenomenon during the first half of the twentieth century, ${ }^{9}$ when it was considered to be complementary to the development of the modern industrial system. ${ }^{10}$

This chapter focuses on the various actors that debated home-based work and mobilized to regulate industrial home work. It begins with the first phase of the mobilization, revealing the role played by women unionists together with women parliamentarians and leaders of women's associations. It then conceptualizes the relationship between industrial home work, Fordism and economic development in post-war Italy. It turns to the years following the first protective law (1958), casting light on women's struggles, including strikes, to see the law enforced. It also considers women's mobilization against increasing job precarity in the mid-196os. The fourth section frames the new mobilization for regulating industrial home work following the May 1968 upheaval in the years of the greatest social conflict of the twentieth century. The chapter concludes by looking at the new spread of industrial home work in the wake of the 1970s' economic crisis. With the 1973 oil shock, the Italian context becomes particularly illuminating of the relationship between post-Fordism and precarious labour.

\section{Women's Agency, Parliamentary Enquiries and Labour Legislation in 1950 s Italy}

Industrial home work attracted wider institutional attention in the 195 os when the Italian parliament launched an official inquiry into workers' conditions, resulting in a regulatory law in 1958. The post-Second World War period saw the legacy of Fascism in cultural as well as juridical terms. Since industrial homebased work was legally defined as "autonomous" in 1924, industrial home workers were officially considered to be self-employed. ${ }^{11}$ The perception of women's industrial home work as complementary work for housewives endured in spite

9 Barbara Curli, "Dalla Grande Guerra alla Grande crisi: I lavori delle donne", in Stefano Musso (ed.), Storia del lavoro in Italia: Il lavoronell'etàindustriale (Rome, 2015), pp. 201-51.

10 Germano Maifreda, La disciplina del lavoro: operai, macchine e fabbriche nella storia italiana (Milan, 2007).

11 Maria Vittoria Ballestrero, Dalla tutela alla parità: La legislazione italiana sul lavoro delle donne (Bologna, 1979). 
of its increasing economic and social necessity. ${ }^{12}$ In the 1950s, industrial home work underwent a process of transformation. In the first half of the decade, home-based work grew in several industrial areas, due to dismissals taking place in Italian factories. ${ }^{13} \mathrm{~A}$ process of productive reconversion, accompanied by a downsizing of the workforce, eventually overlapped with the phenomenon of unfair dismissals targeting members of the labour movement as well as socialist and communist activists, including women belonging to the Union of Italian Women. ${ }^{14}$

Inquiries made by women's associations and the Italian Communist Party revealed that factory downsizing and closures led to a boom in industrial home work, often defined as a "social plague" because it involved whole families (including the young and the elderly). ${ }^{15}$ Noi Donne, the magazine of the left-wing Union of Italian Women (UDI), reported on industrial home work in the Emilia-Romagna region, a key centre for home-based production in the 1950s and 1960s. It showed that men, after dismissal from factories, joined their wives in industrial home work. ${ }^{16}$ Trade unionists and politicians knew about the extent of the practice. They started discussing the regulation of industrial home work in the early 195 os.

During the first half of the decade Giuseppe di Vittorio, general secretary of the Confederazione Generale Italiana del Lavoro (CGIL) and an MP from the ranks of the Communist Party, and Giulio Pastore, general secretary of the Confederazione Italiana Sindacati Lavoratori (CISL) and an MP from the ranks of Christian Democracy, presented two bills in parliament. ${ }^{17}$ Both underscored the growth of industrial home work in the post-war period, and pointed to the absence of any protection for industrial home workers, as well as the high level

12 Eloisa Betti, "Lavoro a domicilio e relazioni di genere negli anni Cinquanta: appunti sul caso bolognese", in Ida Fazio, Aanna Badino and Fiorella Imprenti (eds), Attraverso la città, Genesis, 2 (2015), pp. 107-33.

13 Betti, Lavoro a domicilio e relazioni di genere negli anni Cinquanta.

14 Eloisa Betti, "Gendering political violence in early Cold War Italy: The case of Bologna in Pau Casanellas", in Anna Sofia Ferreira (ed.), Violência política no século XX: Um balanço (Lisbon, 2017).

15 Alessandro Skuk, "78 milioni di salario sottratti ogni mese ai lavoranti a domicilio della provincia: Nostra inchiesta sul lavoro a domicilio", La voce dei lavoratori, 9 October 1954; Rina Picolato, "La piaga sociale del lavoro a domicilio", Rinascita, 6 June 1957.

16 Remo Clementi, “Trappola a domicilio", Noi donne, 3 April 1955.

17 Camera dei Deputati, I Legislatura, Disegni di Legge e Relazioni, Documenti, Proposta di legge di iniziativa dei deputati Giuseppe Di Vittorio, Vittorio Santi et al., Regolamentazione del lavoro a domicilio, annunziata il 7 marzo 1950; Camera dei Deputati, I Legislatura, Disegni di Legge e Relazioni, Documenti, Proposta di legge di iniziativa dei deputati Giulio Pastore, Luigi Morelli et al., Tutela del lavoro a domicilio, annunziata il 28 aprile 195 o. 
of exploitation they experienced daily. The definition of an industrial home worker-as wage worker or self-employed - was a crucial aspect of the debate, together with the need to establish public commissions to oversee the possibility for employers to commission work to home-based workers. They proposed an employers' register to monitor and control the businesses employing home workers.

In spite of the Cold War dynamics, the Communists, Socialists and Christian Democrats within the Italian parliament fruitfully cooperated. A specific committee set up for the purpose drafted a joint text; it included women MPs belonging to different parties, like the Communist Adele Bei, the Socialist Elena Gatti Caporaso and the Christian Democrat Gigliola Valandro. ${ }^{18}$ Women politicians, including key trade unionists like the general secretary of textile workers, Teresa Noce, played an important role in the talks. The Italian parliament and government considered protective regulations necessary. Italian MP s were not in favour of abolishing industrial home work because they realized that home-based work was the sole source of income for thousands of marginal workers, especially women. They began to distinguish between traditional home-based work, related to handicraft manufacturing, and industrial home work, a substitute for factory work. Trade unionists within the parliament proposed to contribute to the definition of piece-rates as well as to establish a Central Commission for industrial home work within the Ministry of Labour. ${ }^{19}$

The Parliamentary Commission of Inquiry into Workers' Conditions in Italy, established in 1955, collected information on the dynamics of industrial home work. The parliament relied on its report to finalize the law on industrial home work. ${ }^{20}$ The Labour Commission of the Lower House nearly unanimously passed a single draft law, which encompassed the previously introduced bills and the Commission's suggestions, in $1957 .{ }^{21}$ The Labour Commission of the

18 Camera dei Deputati, II Legislatura, Commissioni in sede legislativa, XI Commissione, Seduta del 20 aprile 1955, pp. 557-62.

19 Camera dei Deputati, II Legislatura, Commissioni in sede legislativa, XI Commissione, Seduta del 21 novembre 1956, pp. 916-25; Camera dei Deputati, II Legislatura, Commissioni in sede legislativa, XI Commissione, Seduta del 25 gennaio 1957, pp. 1002-08; Camera dei Deputati, II Legislatura, Commissioni in sede legislativa, XI Commissione, Sedute del 30 gennaio 1957, 1 febbraio 1957, 13 febbraio 1957, 15 febbraio 1957, 22 febbraio 1957, 22 marzo 1957 .

20 Camera dei Deputati, II Legislatura, Commissioni in sedelegislativa, XI Commissione, Seduta del 25 gennaio 1957, p. 1000.

21 Camera dei Deputati, II Legislatura, Commissioni in sede legislativa, Seduta del 27 marzo 1957, pp. 1111-22. 
Senate however watered down the draft. Defined as "traditional", home work failed to qualify for unemployment benefits; also reduced were the guarantees demanded of entrepreneurs to join the provincial register of employers. The shared aim of the MPs to make home work more costly, putting it on par with factory work, fell through. The MP s were not in favour of the draft issued by the Labour Commission of the Senate which substantially altered the originally proposed law.

The 1958 law, "Safeguards for home work", excluded workers registered as artisans, a restriction that would be the basis for the extremely limited implementation of the measure, leading to its review in $1973 .{ }^{22}$ There were gains in the 1958 law: the prohibition of entrepreneurial use of intermediaries/subcontractors; the creation of registers at the Provincial Office for Labour, both for home workers and entrepreneurs/employers; the creation of provincial commissions to assess the registrations of the entrepreneurs and to carefully monitor industrial home work; and the establishment of a Central Commission for control at the Ministry for Labour. The law also created a "payroll register" for the entrepreneurs which had to be checked by the Labour Inspectorate, and an employment card for home workers where they had to note down their job description and the related wages. Wage rates in collective bargaining or agreements through provincial commissions were set, based on the highest prevailing piece work rates at the time. Workers registered in the records could apply for the main forms of social insurance (disability, old age, maternity and sickness), but not for unemployment subsidy. The law also introduced a daily fine for any infringement, ranging between 5 ,000 and 20,00o lire. ${ }^{23}$

The debate in parliament was not the only one in the second half of the 1950s. The UDI played a crucial role in denouncing home workers' conditions; it published comprehensive reports in Noi Donne during the years of the economic boom. ${ }^{24}$ Shortly before the passage of the 1958 law, the association initiated a National Congress on Home Workers in Florence on 23 February, 25 which was accompanied by local meetings in numerous other cities including Bologna. These events led to greater awareness not only of women home

22 Decreto del Presidente della Repubblica, Approvazione del regolamento concernente l'applicazione della legge 13 marzo 1958, n. 264, sulla tutela del lavoro a domicilio, approvato il 16 dicembre 1959, pubblicato sulla Gazzetta Ufficiale n. 35 dell'11 febbraio 196o.

23 Ivi, art.2-15.

24 Luisa Melograni, "Prigioniere nella propria casa", Noi Donne, 23 February 1958; Luisa Melograni, "Il ricatto a domicilio", Noi Donne, 12 July 1958; Luisa Melograni, "Voci della città", Noi donne, 8 March 1959. 
workers' conditions but also of their numbers, which ranged between 800,000 and 1 million, according to estimates provided by the association. ${ }^{26}$ Home workers gathered at the Congress in large numbers to raise their voices in protest against their working conditions, revealing the pervasive nature of industrial home work across Italy.

\section{2 \\ Industrial Home Work, Fordism and Economic Development}

Who are these male or female workers? Generally speaking, they are women who, owing to the continuous dismissals that have been taking place in the past few years in industry, were made redundant with no prospect of stable work in an industrial or commercial company. Given the great demands of the families, they have become home workers. Others, and mostly women from the countryside who, having work for just two or three months a year, for the remaining period become home workers. Others still are the same workers employed in the factories who, to round up their wages that very often are below the standard rates, as the employment contracts are not respected, take work to be done at home, in the evening and on public holidays, to support the other family members. This can be seen in particular in the printing sector and that of the papermakers. Others are the women who, albeit being classified as housewives, and not managing to make ends meet with the sole income of their husbands [...] have no chance of leaving the home, either because the children are too small or because there is a lack of essential services like nurseries, and become home workers. ${ }^{27}$

Industrial home work, according to the estimates made by the Parliamentary Commission of Inquiry into Workers' Conditions in Italy, involved between 600,000 and 700,000 workers towards the end of the 1950s, most of them women. The high feminization of industrial home work was the reason why it was treated as an almost exclusively female issue. ${ }^{28}$ Home-based work seemed to be widespread across the whole country, especially the cities of southern Italy (Palermo, Naples, Salerno) and those of the north-east (Venice, Vicenza).

26 Melograni, Prigioniere nella propria casa.

27 Archive of the Union of Italian Women of Bologna (hereafter AUdiBo), b. 2 "Anni ' 50 ", f. "Convegno sul lavoro a domicilio"(Bologna, October 1958). Ibid. 
The crisis that swept across Italy's textile industry in the early 1950s does not seem to have effected a reduction in home-based work, as the rapid growth of the garment industry (knitwear, in particular) offered new opportunities to home workers both in rural and urban areas.

In the late 195os, a broad range of jobs were done at home. Urban areas benefited from geographical proximity to factories. Home work appeared not only in the textile and garment sectors, but also in ceramics, chemicals (pharmaceutical and cosmetics), paper-making and food industries. Even the machine tool industry put out some of its work processes. ${ }^{29}$ In the surroundings of a single factory, Benfenati, for example, there were "fifty-five female workers who perform the most various types of work, from trousers to shoes, from leather goods to toys, from sweet wrapping to doll packaging." ${ }^{30}$

At the dawn of the economic boom, the nexus between industrial home work, Fordism and economic development reflected the precarity of women's labour. The 1958 Bolognese Congress highlighted the heterogeneity of social conditions (i.e. farmer, worker, housewife) and the different contexts of membership (i.e. city, countryside) that accompanied high feminization of labour. The reports of the unions and UDI inquiries show how more and more rural women (sharecroppers and labourers) responded to the decline in traditional rural activities by taking on industrial home work, which was expanding. This was hardly surprising as rural women suffered from chronic underemployment; they were the ones who most lacked farm work in the countryside. ${ }^{31}$ In 1957, researchers Diana Sabbi and Tilde Bolzani claimed that "the definitive abandonment of work in the fields for badly paid and exploitative home working"32 was a generalized trend due to the lack of alternatives.

The structural conditions of the labour market, characterized by high rates of unemployment during the $195 \mathrm{os}^{33}$ and by a very large supply of male and female manpower, facilitated processes of expulsion of labour from the factories; many former female factory workers were forced to be re-employed

29 Commissione parlamentare d'inchiesta sulle condizioni dei lavoratori in Italia, Relazioni della Commissione parlamentare di inchiesta; Nella Prandi, "Lotta Unitaria alla Zucchelli", La voce dei lavoratori, 5 April 1953.

3 о AUdibo, b. 2 "Anni '5o", f. "Convegnosullavoro a domicilio".

31 Maurizio Parasassi and Giorgio Ruffolo, La disoccupazione in Italia: relazione sintetica delle indagini e degli studi promossi dalla Commissione parlamentare dinchiesta sulla disoccupazione (Bologna, 1954).

32 AUdibo, b. 2 "Anni '5o", fasc. "1956", Comunicazione presentata dall'Assessore all'Amm.ne Provinciale Sabbi Diana e dal Consigliere Tilde Bolzani su "I diritti delle donne contadine e la difesa del lavoro femminile nelle campagne".

Parasassi and Ruffolo, La disoccupazione in Italia. 
as home workers simply in order to have an income. ${ }^{34}$ The Parliamentary Commission of Inquiry into Workers' Conditions in Italy highlighted the social consequences of the expansion of industrial home work in various regions of Italy, casting light on the impoverishment of local economies in small and medium-sized urban centres that relied on a limited number of companies. Of particular interest was the point of view of entrepreneurial organizations like the Association of Industrial Employers of Vicenza, expressing concern that the expansion of home work could lead to the contraction or even closure of a whole industrial plant. ${ }^{35}$

The inquiry exposed conditions that made home work the most precarious form of work. It showed in great detail how the closure of factory units corresponded to the installation in homes of former factory workers' looms, previously situated in industrial plants. After being dismissed, the workers were forced to lease or purchase machines simply to be able to continue to work. The inquiry documented the absence of contracts, the lack of worker safeguards in case of sickness, pregnancy, termination or reduction in work, and the instability of wages from piece-work - in short, the exploitation stemming from such a situation. ${ }^{36}$ The pressure to pay in instalments for the purchase of machines along with the very low piece-work rates forced women home workers to extend their working hours beyond the limits of physical endurance, reaching an average of 12 to even 14 hours per day. ${ }^{37}$ In the garment sector, the wage of a specialized factory "machinist" was 1,238.32 lire for 8 hours' work, while that of a home worker doing the same job was at most 1,040 lire. ${ }^{38}$

Generally speaking, the machinist needs two-and-a-quarter hours to twoand-a-half hours per piece, provided that she does not leave the machine. Thus, the wool spindles had to be ready to pick up those ladders that can happen here and there during the work, and so she must add from 20 to 30 minutes per piece, coming to 3 hours each. If we consider that they are paid 430 lire a piece, reaching an average of 130 lire per hour, [...] if she works 8 hours as the worker does in the factory, she would reach a daily wage of 1,040 lire. ${ }^{39}$

34 Betti, Lavoro a domicilio e relazioni di genere negli anni Cinquanta.

35 Commissione parlamentare d'inchiesta sulle condizioni dei lavoratori in Italia, Relazioni della Commissione parlamentare di inchiesta.

36 Ibid.

37 Ibid.

38 "I dibattito del Comitato Cittadino : Ducati e lavoro a domicilio", La lotta, 3 March 196o.

39 Ibid. 


\section{Industrial Home Workers' Strikes and Women's Mobilization against Job Precarity in 196os Italy}

The competitive nature of industrial home work during subsequent industrial growth led to slower and less successful implementation of the 1958 law than expected. The persistence of very high levels of exploitation and the expansion of home work in the years of the economic boom precipitated the first significant struggles. In March 1960, over 1,20o home workers living in the rural municipalities of the eastern Bolognese plains (San Giovanni in Persiceto, Crevalcore, Sant'Agata, Anzola dell'Emilia and Sala Bolognese) went on strike with the combined support of the unions. They marched on the streets of their respective town centres. The striking workers demanded increased rates of pay, continuity of work and enforcement of the 1958 law. 40

Just weeks earlier, on 11 February 1960, the President of the Republic had signed the "Safeguards for Home Work" regulation to enforce the law passed two years earlier, which threatened employer profits. Therefore, to evade the obligations imposed by the new law, employers started blackmailing the home workers, urging them to become artisans if they did not want to lose their jobs. This strategy fostered the development of artisanal companies paying very low wages, often lower than that of a "third level" shop floor worker. ${ }^{41}$ The employers' blackmailing strategy meant a further worsening of working conditions. Once the home workers became artisans, they were forced to bear all the costs related to their status, in addition to the cost of purchasing or leasing the machines they needed to do their work. Being registered as artisans was incompatible with the working conditions of the home workers. They lost all the benefits the law gave them as home workers, including, first and foremost, contributions from the "employer" relating to health care and pensions. ${ }^{42}$

This was the context that generated the first important forms of protest initiated by the home workers themselves. The strike that took place on $2 \mathrm{March}$ 1960 represented a break with the past. There had been few previous occasions when home workers made their voices heard as a group. The fear of appearing in public was widespread, since the risk of losing their jobs was particularly high due to the informal character of industrial home work. Notwithstanding its widespread nature in the province of Bologna, home work had remained

40 "Ha rivelato un quadro impressionante lo sciopero dei lavoranti a domicilio", l'Unità, Cronaca di Bologna, 6 March 196o.

41 Remo Cappelli, "La tessera del pane per le lavoranti a domicilio?", La lotta, 10 March 196o.

42 Ballestrero, Dalla tutela alla parità. 
until then an "invisible" form of work. A City Committee was set up to support the organization of the strike. A meeting laid out some of the priorities, especially the need to break down the wall of isolation behind which the women workers lived, with a view to help them to come together. Besides the 2 March strike, home workers initiated other forms of collaboration. In the municipalities of Sant'Agata, Sala Bolognese and San Giovanni in Persiceto, groups of knitwear workers established autonomous groups with the support of the union, moving towards the creation of full-fledged cooperatives. ${ }^{43}$

Women home workers were a subject of renewed attention from leftwing political and union organizations, first and foremost the PCI (Partito Comunista Italiana/Italian Communist Party) and the C GIL, and then the UDI. The PCI leadership judged home work negatively because it took women away from participation in public life, reducing their potential unionization and politicization. ${ }^{44}$ The rank-and-file of the party, on the contrary, saw in home work the right balance between the fulfilment of the family's economic needs and the carrying out of care responsibilities. In the early 196os, home work was at the centre of discussions within the women's commission of the Bolognese PCI, which stressed the difficulty of "organizing" home workers: only 250 home workers had been "organized" in Bologna, spread across the main workingclass neighbourhoods and the central area of the city. ${ }^{45}$ The UDI indeed played an important role in promoting the socialization and organization of home workers through the so-called "riunioni di caseggiato", which pushed home workers to step out of their houses and discuss their problems in informal gatherings. ${ }^{46}$ Some of the leaflets of 1960 urged home workers to emerge from their invisibility and achieve their legal rights. ${ }^{47}$ The emphasis was once again on the isolation that women workers had to endure: the UDI promised not to

43 Cappelli, "La tessera del pane per le lavoranti a domicilio?".

44 Fondazione Gramsci Emilia-Romagna (hearafter FGER), Archivio del Partito Comunista Italiana (PCI)-Federazione Provinciale di Bologna (hearafter APCIBO), Section "Commissioni, Sezioni di lavoro e Dipartimenti", Sub-section "Commissione femminile", f. 2 "Problemi della politica del PCI verso le donne 1953-1959", dattiloscritto (Tilde Bolzani 1953).

45 FGER, АРсiвo, Section "Commissioni, Sezioni di lavoro e Dipartimenti", Sub-section "Commissione femminile", f. 3 "Posizione partiti sulla condizione femminile 1953-196o", Risoluzione della sezione femminile e lavoro di massa della direzione PCI ( 5 dicembre 1959), Sviluppo dell'azione per la tutela del lavoro a domicilio (Marzo 196o).

46 Numerous ways at reaching out to home workers were attempted by the UDI, particularly evident in the association's leaflets: AUDIBо, b. 1 "Storia GDD e UDI 1944-1964", f. "Volantini e stampa di archivio", 1958, [Ricamatrice, Confezionista, Magliaia, Pantalonaia, Guantaia]. AUDIBO, busta n. 3, "1960-1963", fascicolo cat. III. 
leave the home workers alone, guaranteeing them support and a help-desk at the association's offices.

A few years later, during the $1963-64$ economic crisis following the economic boom, about 300,000 Italian women lost paid work. Once they were ousted from the production cycle, especially if employed in industry, women could no longer find regular work and were relegated to the informal economy, once again swelling the ranks of home workers. Between 1963 and 1965, the UDI published numerous studies on the effects of the crisis on female workers. ${ }^{48}$ The aim was to understand how women reacted to the "great fear of unemployment", and their conditions of life and work during the crisis. The UDI's main slogan became, "We are not going home"; a recurring question it posed was, "Where is the miracle?"49 Italian women workers and their associations demanded job stability along with an end to job precarity. In 1965, the UDI held a national conference in Milan followed by a large demonstration of more than 4,0oo women. The title of the conference, which became the demonstration's major slogan, was "Women's right to stable and qualified work", testifying to the UDI's innovative approach. ${ }^{50}$

\section{Industrial Home Workers as Wage Workers: The Struggle for} Recognition, $1968-73$

Today home work is no longer just a complementary activity to round up household income and, as such, entrusted to the housewife, the pensioner, the farmer's wife or the worker dismissed from the crisis-hit textile company. Instead it is based on a multitude of young workers searching for their first job, female workers marginalized from the factory in the years of economic recession and in unfavourable phases, who did in fact all work within a decentralized organization but with industrial machines. The result of which is a cut in the labour costs achieved by means of the payment of

48 "A casa non si torna", Noi Donne, 5 Dicember 1964; "300 giorni perduti", Noi Donne, 28 November 1964 .

49 "A casa non si torna".

$5^{\circ}$ National Archive of the Union of Italian Women (hearafter NAUDI), chronological section, 1965 , b. 112, f. 894, Per il diritto delle donne al lavoro stabile e qualificato, Atti della conferenza nazionale (Milan, 12-13 giugno 1965). 
lower wages to the contractual workers and bypassing of the obligations stemming from social legislation. ${ }^{51}$

The continuous increase in home-based work in the mid-196os led to renewed parliamentary discussions in the wake of the May 1968 upheaval, the greatest social conflict of the twentieth century. The 1973 law, "New norms for safeguarding home work", followed the Statute of Workers' Rights, which represented the most important Italian labour law of the twentieth century.52 Women MP s played a pivotal role in passing the 1973 law on industrial home work. They were the first signatories of the bills presented by different political parties, supporting the struggle of industrial home workers to be recognized as wage workers. The parliamentary process that led to the new law on industrial home work was shorter than the one that ended in $1958 . .^{53}$ The first proposal was presented just prior to the so-called "hot autumn" of 1969 and followed the national conference on female employment of February 1968, which provided relevant elements for an understanding of the evolution of home-based work. ${ }^{54}$

The first bill, presented in December 1969, was signed by the Communist MP Luciana Sgarbi, followed by NildeIotti, Nives Gessi and many other politicians belonging to the same party. ${ }^{55}$ An accompanying report outlined the failed enforcement of the 1958 law. This negative assessment was shared by the Under-Secretary to the Ministry for Labour and by the main unions, CGIL (Confederazione Generale Italiana del Lavoro/Italian General Confederation of Labour), cisL (Confederazione Italiana Sindacati Lavoratori/ Italian Confederation of Workers' Trade Unions) and UIL (Unione Italiana del Lavoro/Italian Labour Union).${ }^{56}$ According to the latter, the most critical aspect

$5^{1}$ Camera dei Deputati, vi Legislatura, Disegni di Legge e Relazioni, Documenti, Disegno di legge presentato dal Ministro del Lavoro e della Previdenza Sociale Dionigi Coppo, di concerto con il Ministro di Grazia e Giustizia, Guido Gonnella e il Ministro dell'Industria, Commercio e Artigianato Mauro Ferri, Nuove norme per il lavoro a domicilio, presentato alla Presidenza il 16 aprile 1973 .

$5^{2}$ Paolo Mattera, "Legislazione sociale e welfare", in Musso (ed.), Il Novecento, 1945-200o, pp. $378-415$.

53 Marcello De Cristofaro, Il lavoro a domicilio (Padua, 1978).

54 Ministero del bilancio e della programmazione, Conferenza sull'occupazione femminile (Rome, 1968).

55 Camera dei deputati, v Legislatura, Disegni di Legge e Relazioni, Documenti, Proposta di legge di iniziativa dei deputati Luciana Sgarbi, Nilde Iotti et al., Modifiche alla legge 13 marzo 1958, n. 264, concernente la tutela del lavoro a domicilio, annunziata il 19 dicembre 1969 , p. 3 . 
was the large number of home workers registering as artisans, often blackmailed by employers who threatened them with denial of any more work. In 1968 , it was estimated that there were between 1 million and 1.5 million home workers, as compared to just 24,000 formally registered as such. The growth of home work as the last productive unit of the Italian industrial system coincided with a major decline in female employment, of around 1,200,000 workers. Hence, the bill aimed to increase the cost of home-based work, pushing entrepreneurs to make greater investments and re-absorb the external workforce. As a safeguard, the juridical redefinition of the home worker as a subordinate worker was considered essential, along with the extension of all the social benefits granted to factory workers.

In January 1973, the Socialist lawyer and M P Maria Magnani Noya presented a new bill. ${ }^{57}$ Its short accompanying report highlighted the abuses and violations made possible by the omissions and the ambiguities of the 1958 law. Redefining the figure of the home worker, making explicit her subordination, and clarifying the distinction between home-based work and entrepreneurial activities, became the focal aspects. In March 1973, Tina Anselmi, ${ }^{58}$ who had worked for long as a unionist for CISL and was appointed as Minister for Labour only a few years later, was the first signatory of a Christian Democrat bill. This draft reviewed the definition of home worker in line with previous proposals, specifying that workers who leased machines and equipment from a company were to be considered employees of the latter. It introduced a clause aimed at tighter regulation of the use of home work in company restructuring: it forbade companies affected by dismissals and lay-offs to outsource work. Anselmi's proposal also addressed problems of hygiene and health, forbidding the implementation of processes ${ }^{59}$ that involved the use of substances harmful to the well-being of the workers and their families at home. After these bills of law came the government's draft law, "New norms for home working".

Tina Anselmi led a committee to draft a joint bill. She highlighted the great attention that the issue of home work had attracted in the press and in public opinion, as well as among local institutions, trade unions, women's associations

57 Camera dei Deputati, vi Legislatura, Disegni di Legge e Relazioni, Documenti, Proposta di legge di iniziativa dei deputati Magnani Noya Maria, Alfredo Giovanardi et al., Modifiche alla legge 13 marzo 1958, n. 264, recante norme per la tutela del lavoro domicilio, annunziata il 27 gennaio 1973 .

58 Camera dei Deputati, vi Legislatura, Disegni di Legge e Relazioni, Documenti, Proposta di legge di iniziativa dei deputati Anselmi Tina, Vincenzo Mancini et al., Modifica della legge 13 marzo 1958, n. 264, per la tutela del lavoro domicilio, annunziata il 14 febbraio 1973. The proposal put forward the drafting of a table of harmful processes by the Ministry for Labour, acting in synergy with the Ministry of Health. 
and, of course, among the workers themselves, most of them women. ${ }^{60}$ MP s sought to define home work more precisely to safeguard it against illegality and to better safeguard the workers, as well as reduce the causes of its abnormal and distorted spread. Luciana Sgarbi Bompani and Magnani Noya Maria highlighted the intersection between the decline in female employment and the expansion of home work as the sole source of income for many women. ${ }^{61}$ However, opinions on the role (positive or negative) of industrial home work varied, showing the persistence of the housewife model, especially within certain parts of the Catholic milieu. The Christian Democrat Ines Boffardi underlined that "when home work does not degenerate into irregular situations and thus illegal acts of exploitation, it always represents a qualifying and dignified means to allow the female worker to perform a profitable activity without abandoning her home and her family".62

In December 1973, the new law on home work was enacted, whereby home workers were recognized as equal to factory workers. ${ }^{63}$ There was now the possibility to bargain with employers over piece-rates, through the unions. Thousands of home workers, once legalized, would at last be able to enjoy all the social guarantees available to the factory workers related to illness, maternity leave and redundancy. The law also did away with the incompatibility between enrolment in the artisans' registers and the registers of home workers. It forbade the use of home work for harmful processes, and after restructuring or conversions leading to layoffs or dismissals.

\section{5 \\ The Explosion of Home-based Work in the Wake of the Fordist Crisis: Critiques and Mobilization of Unions and Women}

As shown by Tania Toffanin, the decentralization of production in the 1970s produced a fresh rise in home-based work in all areas of the country.64 The 1973 law created an opportunity to improve and stabilize home workers' conditions, defining them as subordinate workers and ensuring that they had access

60 Camera dei Deputati, vi Legislatura, XIII Commissione, sedute del 4 ottobre 1973, pp. 242-47.

61 Ibid., pp. $247-5$ o.

62 Camera dei Deputati, vi Legislatura, XıII Commissione, sedute del 10 ottobre 1973, pp. 264.

63 Legge n. 877 , Nuove norme per la tutela del lavoro a domicilio, approvata il 18 dicembre 1973 e pubblicata sulla Gazzetta ufficiale n. 5 del 5 gennaio 1974 .

64 Tania Toffanin, Fabbriche invisibili: storie di donne, lavoranti a domicilio (Verona, 2016). 
to the main social guarantees connected to work. It was unable, however, to slow the growth of industrial home work, although it set limits to its use in the case of restructuring that involved cuts in employment. ${ }^{65}$ The possibility to reduce labour costs as well as the entrepreneurial desire to achieve the "greatest possible flexibility in the use of workforce" lay behind the (new) increase of industrial home work, which was accompanied by a parallel growth of small firms. The textiles-garments sector was at the centre of numerous studies in the 1970s, initiated by both economists and sociologists, also in collaboration with trade unions. ${ }^{66}$

The most important of these, conducted by Luigi Frey, ${ }^{67}$ studied the relationship between production decentralization and home work expansion in textiles-garments. Italy responded to the crisis of Fordism by decentralizing industrial production, which became more and more evident in the second half of the 1970s after the oil shock. Researchers considered home work to be the last unit of production in the decentralized factory, which they analysed alongside small companies and artisanal businesses. Decentralization appeared to be stronger where there was a concentration of unemployed or underemployed personnel willing to accept lower wages, especially women, youth and elderly people. ${ }^{68}$ Women accounted for 90 per cent of home workers due to a lack of alternatives. Often classified as housewives in the official statistics, many home workers came from backgrounds of rural underemployment, marked by a prevalence of female and youth unemployment. ${ }^{69}$

Specific studies were conducted on the conditions of female industrial home workers. Among these, Operaie senza fabbrica (1977) by Maria Rosa Cutrufelli, offered in its very title a full-fledged conceptual category that informed subsequent debate. Cutrufelli highlighted the worsening of female job precarity since the late 196os, "the expulsion of a substantial number of female workers from the market of stable work" to "the area of marginal and precarious work". ${ }^{70}$ Female workers were the true protagonists of the process of industrial restructuring that had developed outside the factory. The situation of the labour market, together with women's family responsibilities, were the chief

65 Luigi Mariucci, Il lavoro decentrato : Discipline legislative e contrattuali (Milan, 1979).

66 Sandro Del Giudice and Galvano Pizzol (eds), Ristrutturazione produttiva e lavoro a domicilio : Indagine sul decentramento produttivodell'industriatessile, dell'abbigliamento e delle calzature in provincia di Treviso (Verona, 1975).

67 Frey, Lavora domicilio e decentramento dell'attività produttiva.

68 Ibid.

69 Ibid.

$70 \quad$ Maria Rosa Cutrufelli, Operaie senza fabbrica (Rome, 1977), p. 16. 
causes of diminished stability and greater precarity among female workers. Married women with children appeared to be over-represented in industrial home work and in undocumented work at large, owing to the impossibility of finding jobs that might allow them to combine productive and reproductive work. ${ }^{71}$ According to Cutrufelli, behind the high rates of female workers' turnover in factories was the unresolved question of household management.

The explosion of industrial home work in the 1970s led to a new mobilization, which saw the involvement of trade unions and women's associations influenced by a second-wave feminism. With the worsening of that decade's economic crisis, precarity, marginalization and disqualification increased significantly, especially among younger women, due to the exponential growth in home-based work and undocumented labour following the process of industrial restructuring. The expansion of industrial home work and the rise in female unemployment produced a renewed elaboration and mobilization on the part of the UDI, as its political strategy closely linked the right to paid work and social progress. In February 1976, the association led a national demonstration dedicated to female employment, protesting the "secondary", "peripheral" economy of which women increasingly tended to be the protagonists during the crisis years. ${ }^{72}$

UDI's critique was directed towards both the organization of workplaces and women's role in society and in the family. It rejected the concept of being "a housewife" as a "fate" not chosen by women, for obscuring female unemployment and underemployment and weakening women's claims to fair compensation and other rights. Alongside the trade unions, the association conducted numerous studies on home-based work in various parts of the country. A new generation of women unionists directed their actions towards home workers, above all in the regions that were most affected such as Emilia-Romagna. ${ }^{73}$ They organized numerous rallies and conferences to inform home workers of the new law. They undertook several inquiries into home workers' conditions, alongside bargaining for better piece-rates. ${ }^{74}$ The fact that these actions were not always effective paved the way for self-organization, such as the "unitary league for home work" of Naples set up in $19755^{75}$

71 Ibid.

72 NAUdi, Thematic Section, Diritto Al Lavoro, b. 26, f. 161, Manifestazione Nazionale Dell'unione Donne Italiane 11 Febbraio 1976 (Conclusioni Margherita Repetto).

73 Leonardo Tommasetta, Il lavoro a domicilio nell'Emilia-Romagna (Bologna, 1977); Renato Zangheri, "Caratteri dell'economia emiliano-romagnola", in Atti dell'Accademia delle scienze dell'istituto di Bologna, Rendiconti, LXVI (1978).

74 "Illavoro a domicilio", in QuadernidiRassegna sindacale, 44-45, September-Dicember 1973.

75 Toffanin, Fabbriche invisibili. 
Industrial home work coexisted and spread along with the Fordist factory system, contributing to a "dual" labour market. It was a crucial element in the massive industrial growth of twentieth-century Italy, especially in textiles and garments where it became the backbone of industrial production. Industrial home work did not undergo any crisis in the Golden Age period of the twentieth century, even as its function was partially reshaped by the changes taking place in the industrial system. Home-based work was supported by factory owners, who often directly subcontracted a part of their production to home workers. The competitive character of industrial home work, together with the lack of other employment opportunities, especially for women, created the basis for its pervasiveness. During the economic crisis experienced by Italy in $1963 / 64$, industrial home work grew significantly due to its low cost and flexibility. Again, during the crisis of the Fordist system, home-based work saw renewed and massive expansion.

Although difficult to enforce, legislation on industrial home work, conceived and established during the Fordist period, showed a political commitment towards improving the conditions of industrial home workers. Women played a crucial role in advancing industrial home work regulation as well as in exposing the conditions of industrial home workers. Women's agency was an important aspect of Italian discussion and mobilization in the sphere of industrial home work, while the actions of unionists within parliament were also crucial. Abolishing industrial home work was never part of the Italian debate in the Golden Age, as it was considered a necessary source of employment despite its negative characteristics. Only in the early 1970s, in the wake of the Fordist crisis, were concrete attempts made to balance the relationship between factory work and industrial home work.

Industrial home work in Italy was a continuous phenomenon over the twentieth century, going beyond established periodization. The importance of understanding industrial home work as part of the national industrial structure clearly emerges in the Italian context. Moreover, it underscores the significant role played by women, as unionists and politicians, in regulating industrial home work, which also happened elsewhere, as other chapters in this volume indicate. 